\title{
Factors Affecting a Business Strategy and its Impact on Construction Services in a Special Area of Jakarta: Balanced Scorecard and Malcolm Baldrige Approach
}

\author{
M. Noor Salim \\ Universitas Mercu Buana, Indonesia \\ E-mail: m_noorsalim@yahoo.com
}

Received: June 4, 2018 Accepted: June 14, 2018 Published: June 30, 2018

doi:10.5296/bms.v9i1.13251ＵRL: https://doi.org/10.5296/bms.v9i1.13251

\begin{abstract}
Research in the field of strategic management is intended to test and analyze the influence of the external and internal environment of the organization on the performance of construction service companies through the business strategy of construction service companies. This research uses balanced scorecard and Malcolm Baldrige integration approach. Innovation on performance merging as measured by Balanced Scorecard and Malcolm Baldrige performance. Variable research includes external environment variables, internal environment, business strategy and performance of construction company services. The method of analysis is done by Structural Equation Modeling (SEM) model. The external environment influences the performance of construction services through business strategy, it shows that the dynamic influence of the external environment explores the macro strength and competition analysis it is necessary to apply the right strategy through business quality and partnership strategy then the performance of construction services will be increasing. Internal environment affects the performance of construction services through business strategy, it shows that the dynamic influence of the internal environment through the culture, structure and sources of the organization it is necessary for the implementation of appropriate strategies through business quality and partnership strategy so that the performance of construction services will getting up.
\end{abstract}

Keywords: external environment, internal organization, performance of construction Service Company, business strategy of construction Service Company 


\section{Introduction}

The role of the construction sector in Indonesia to the national economic development increased from $9.51 \%$ in 2015 to $9.88 \%$ in 2016. In terms of employment opportunities, the performance of the construction sector is also able to absorb a large enough workforce. This is because the number of construction companies which operates in Indonesia is quite large at about 129,819 companies in 2016. The value of construction industry is 146,407.228 million rupiah with $13.52 \%$ growth with 166,171 employees (BPS, 2015). Service areas currently face a wide range of jobs ranging from a wide range of jobs, jobs performed between contractors, low employment, low labor and large labor, increasing numbers, to limited construction information. often needed to be used as materials to make the builders done so far. Development in the Region of DKI Jakarta Province (jutar Rupiah) is quite good compared to other provinces. The value of construction increased from Rp. 91.438 .995 (2011) to Rp. 146,407,228 (2015) or an average increase of $25.52 \%$ per annum on average. In the midst of tight business competition conditions, the construction services business in Indonesia to maintain the survival of the company. Success in the construction services industry is closely related to the smoothness of the overall development process.

The external environmental conditions of construction services companies in Indonesia (economic, political and socio-cultural conditions) are currently being addressed by companies through the implementation of strategies to survive (Porter 2008). Meanwhile, the internal environment as internal strategic factors in the form of strengths and weaknesses in the form of organizational culture, organizational systems and organizational resources that can determine whether the company is able to take opportunity and avoid threaten (Wheelen and Hunger, 2013). This highly dynamic change of environment requires adequate strategies to drive the achievement of corporate goals. For that need to do continuous research to compensate for the dynamic business conditions.

Performance measurement is done by merging Balance Scorecard and Malcolm Baldrige performance, through similarity of function of each Balance Score Card (financial perspective, customer perspective internal business process perspective and learning and growth perspective) and Malcom Baldrige (leadership, strategic planning, market focus, information analysis, process management and Malcolm Baldrige results)

This research analyzes the external and internal environment of the strategy and its impact on the performance of the integrated system with Balanced Scorecard and Malcolm Baldrige. Innovation on the merge of performance in accordance with Balance Scorecard and Malcolm Baldrige performance, with first mapping and discovery of function between Balanced Scorecard is financial perspective, customer perspectives, internal processes, and perspectives with Malcom Baldrige are leadership, strategic planning, market focus, information analysis, management processes and outcomes Malcolm Baldrige. External factors that became the goal is the level of difficulty in Indonesia which has ranked 114 among ASEAN countries. This is one of the relative symptoms of business difficulties in Indonesia. For details the ratings can be used in the table below (World Bank, 2016). 
Table 1. Country Rating

\begin{tabular}{|c|c|}
\hline Country & Rank \\
\hline Singapore & 1 \\
\hline Malaysia & 18 \\
\hline Thailand & 26 \\
\hline Vietnam & 78 \\
\hline Phillipines & 95 \\
\hline Brunei Darussalam & 101 \\
\hline Indonesia & 114 \\
\hline Cambodia & 135 \\
\hline Laos & 148 \\
\hline Myanmar & 177 \\
\hline
\end{tabular}

Strategic management research that analyzes the influence of the external and internal environments on business strategy and the impact on the performance of construction company services. This research uses balanced scorecard and Malcolm Baldrige integration approach. Innovation on performance merging as measured by Balanced Scorecard and Malcolm Baldrige performance, with first mapping and similarity of function between Balanced Score Card that is financial perspective, customer perspective internal perspective of business process and learning and growth perspective with Malcom Baldrige performance that is leadership, strategic planning, market focus, information analysis, processing management and the results of Malcolm Baldrige. In this combined model, the BSC (Balanced Scorecard) perspective is replaced by MBNQA (Malcolm Baldrige National Quality Award) perspective of leadership and work focus; further internal business process perspective is replaced by process management, strategy planning and knowledge management located on Malcolm Baldrige; while the consumer perspective in the balanced scorecard is considered equivalent to the customer and market focus; as well as the perspective of financial performance in the balanced scorecard is considered equivalent to the outcome of Malcolm Baldrige

\section{Literature Review}

The internal environment as well as the external environment of the business is an organizational environment and should be considered in business decision making to determine the choice of business strategy. The external environment is an environment that must be observed to determine opportunities and threats. The social environment to consider includes (1). Economic Strength, (2). The Power of Technology, (3). Legal-political power, and (4). The Power of Socio-Culture (Hunger, 2012). Furthermore, Buffet and Munger (2010) reveals five competitive forces: Competition from Substitutes, Threats of Entry, Rivalry Between Established Competitors, Bargaining Power of Buyers, and Bargaining Power of Suppliers (competition from substitutions, threats of newcomers, competition built by competitors, the strength of the buyer's offer, the strength of the buyer's offerings, and the 
supplier's supply strength). The framework of industry competition is classified into 1) Threat of Potential Entrants (potential new potential threats); 2) Rivalry Determinants (competition determinants); 3) Determinants of Buyer Power, 4) Determinants of Supplier Power, 5) Determinants of Substitution Threats (McCann, 2011). The strength of strategy in competition will be the basis for getting the right position and determined by the five competitive forces, (1) threat of entry of newcomers, (2) suppliers bargaining power, (3) bargaining power of buyers, (4) substitution product threat, and (5) competition in the industry. In order to occupy a competitive position in the industry then the company must be able to minimize the impact of these five forces. Competition among industries is done in various ways such as price competition, product introduction and advertising war.

Ting Chi (2015) analyzes the business environment against strategic priorities and business performance; dimensional variables of the business environment are the industrial environment, the operating environment, the remote environment, the internal environment. Altuntas et al. (2014) analyzes the influence of industrial environments on organizational strategies and performance such as competition threats, new threats, buyer threats, supplier threats and organizational resources. Kamau and Stanley (2015) analyzed the factors that influence the choice of strategy, the variable dimensions of the business environment are industry competition, leadership, industry competition. Dauda and Ismalia (2013) analyze the strategy environment against the choice of strategy, which includes the business environment is the technological environment. The essence of competitive strategy can be described as a process of how a company develops and develops its strategic resources that have the potential to produce competitive advantage, whichever advantage can be ambiguous on the one hand as an instrument for performance and on the other as an instrument to neutralize assets and competencies competing owned by competitors.

Some opinions of competing theories raised by some resource such as: Ibn Hajar (2015) analyzes the influence of business strategy on innovation and performance, business strategy variable dimension is the type of prospector, analyst (analyzer) and defender. Kamau and Stanley (2015) analyzed the factors that influenced the choice of strategy, the variable dimension of strategy choice was benchmarking and standards. Arasa and Loice, (2014) analyzes competitive strategies for performance, the variance dimension of competitive strategy of cost leadership strategy, market focus strategy, alliance strategy and differentiation strategy. Arasa and Obonyo (2012) analyzed the strategic planning that influences the performance, the variable dimension of strategic planning is the determination of the purpose and objectives, the business environment analysis, strategic issue analysis, the strategy slot analysis and implementation strategy, evaluation and control framework.

Reengineering aims at current business processes and activities that contribute to the value of creation. This can be done for flexibility and social modernization, through a radical redesign of the organization. The application of reengineering can promise a drastic change in corporate organization and business processes. If reengineering is successful then the company will be able to improve the performance of the organization and its employees 
(Davidson, 2014). But on the contrary, if the reengineering effort fails then the risk experienced by the company will arise. Organizational performance or company performance is an achievement level indicator that can be achieved and reflects the success of managers. Information on organizational performance can be used to evaluate whether the work process undertaken by the organization has so far been aligned with the intended purpose. But in reality many organizations are actually less or even rarely there are no information about the performance in the organization.

Measurement of organizational performance can be done, as follows.

a. The measurement of corporate performance with the Balanced Scorecard (BSC) approach is the most popular performance measurement today. The main advantage of this performance measurement is comprehensive, that is, the measurement of performance not only on the internal aspects of the company but on the external aspect of the customer perspective. In addition, the other advantages are integrative, meaning the four perspectives that exist in the BSC (Balanced Scorecard), namely: (1) financial, (2) customers, (3) internal business processes, and (4) growth and learning organization, interrelated.

b. The BSC (Balanced Scorecard) does not provide a definite performance measure, and the measurement of each performance indicator in all four BSC perspectives (Balanced Scorecard) is measured by different measurement methods making it difficult to compare the measurements at each perspective. For example is the Financial Perspective measured by using financial ratios obtained through secondary data financial statements, while on the perspective of customers using the scale of Customer Satisfaction obtained through customer satisfaction survey.

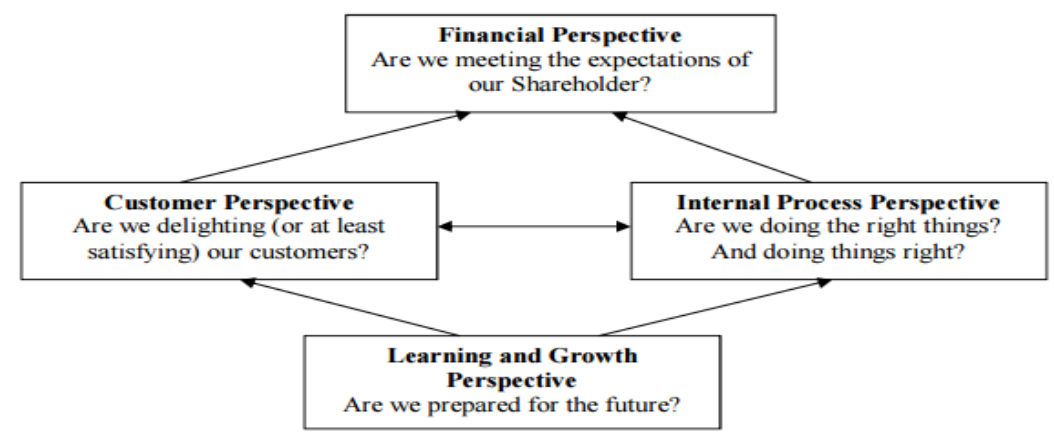

Source: Adapted from Robert S. Kaplan and David P. Norton, "Using the Balanced Scorecard as a Strategic Management System," Harvard Business Review (January-February 1996): 76. (Hunger, 2012)

Baldrige assessment aims to measure performance. MBNQA (Malcolm Baldrge National Quality Award) is a reward program based on organizational achievement of Malcolm Baldrige Criteria for Performance Excellence (MBCfPE), or abbreviated Baldridge Criteria Baldrige assessment can help organizations deal with dynamic environments, high work system, translate vision and mission into strategy, build short-term success and organizational stability for long term (Gaspersz, 2011). Malcolm Baldrige as a tool that measures and 
evaluates the performance of management and is integrated into 7 categories: leadership, strategic planning, customer, stakeholder, and market focus (customer, stakeholder, market focus), measurement, measurement, analysis, and knowledge management, focus on workforce focus, process management, and organizational performance result

Gaspersz (2011) states, there are six basic reasons why local and world-class organizations choose Baldrige Assessment as the framework of the management system. Those reasons are (1) Baldrige Assessment is able to identify any strengths and opportunities for improvement or opportunity for improvement (OFI) from various areas within the organization related to the seven MBNQA criteria; (2) The Baldrige Assessment provides a framework for improvement towards performance excellence by providing management freedom to implement independent business strategies and performance enhancement programs; (3) Baldrige Assessment is an integrated management framework, covering all the factors that define the organization, operational processes and results of a clear and measurable performance; (4) Baldrige Assessment focuses on requirements to achieve performance excellence, not just applications, procedures, tools or techniques; (5) Baldrige Assessment is adaptable to the business environment, applicable to large and small organizations, local organizations operating only in a country or world class operating in many countries; (6) Baldrige Assessment has proven to be a valid global management practice to improve organizational performance excellence

The criteria for measuring Malcolm Baldrige Criteria are as follows: (1) Leadership shows how senior leaders can guide and sustain organizations, organize organizational vision, values, and performance expectations. Attention is given to how senior leaders communicate with staff, develop future leaders, and create an environment that encourages high ethical behavior and performance; (2) Strategic planning (strategic planning), Category strategic planning test how to develop objectives and strategic action plan. Also tested is how to select strategic outcomes and action plans to propagate and change if circumstances change, and how progress will be measured; (3) Focus on customers, stakeholders, and markets (student, stakeholder, and market focus). Customer focus tests how an organization determines customer needs, expectations, and choices. Other things that are tested are how the organization builds customer relationships, determines key factors that drive towards its goals, customer satisfaction and loyalty as well as expansion into service; (4) Measurement, analysis and knowledge management Measurement, analysis, and knowledge criteria examines how an organization chooses, obtains, analyzes, regulates, and develops its data, information, and knowledge assets. It also examines how an organization reviews its performance; (5) Workforce focus, Workforce focus criteria checks the organization's ability to assess employment capability and capacity and builds a conducive working environment for good performance. Workforce focus criteria also look at how organizations drive, manage, and develop workforce potential in line with the organization's mission, strategy, and corporate action plans; (6) Process management, this criterion examines how organizations design, manage, and improve the work of systems and work processes for customer and stakeholder satisfaction and achieve organizational success and sustainability; (7) 


\section{Macrothink}

Organizational performance result, this criterion examines the performance and improvement of the organization within the scope of the results of the services provided, customer satisfaction and other customer, financial and market performance, the results of staff and work system, performance operational, leadership and community responsibilities.

\section{Research Method}

Examining the influence of external and internal environments on business strategy and its impact on the performance of construction service firms as measured by Malcolm Baldrige's integration model and Balance Scorecard in Jakarta's Special Capital Region. Population is contractor of big and medium company of construction service from model of Krejcie and Morgan (Uma Sekaran, 2012). The sampling technique is done by simple random sampling. A random sample of 340 samples was obtained based on the number of samples selected from 2939 construction service companies with the formula Krejcie and Morgan (Uma Sekaran, 2012). Research variables include external environment variables, internal environment, and business strategy and service performance of construction companies. Analytical approach is done with Structural Equation Modeling (SEM) model.

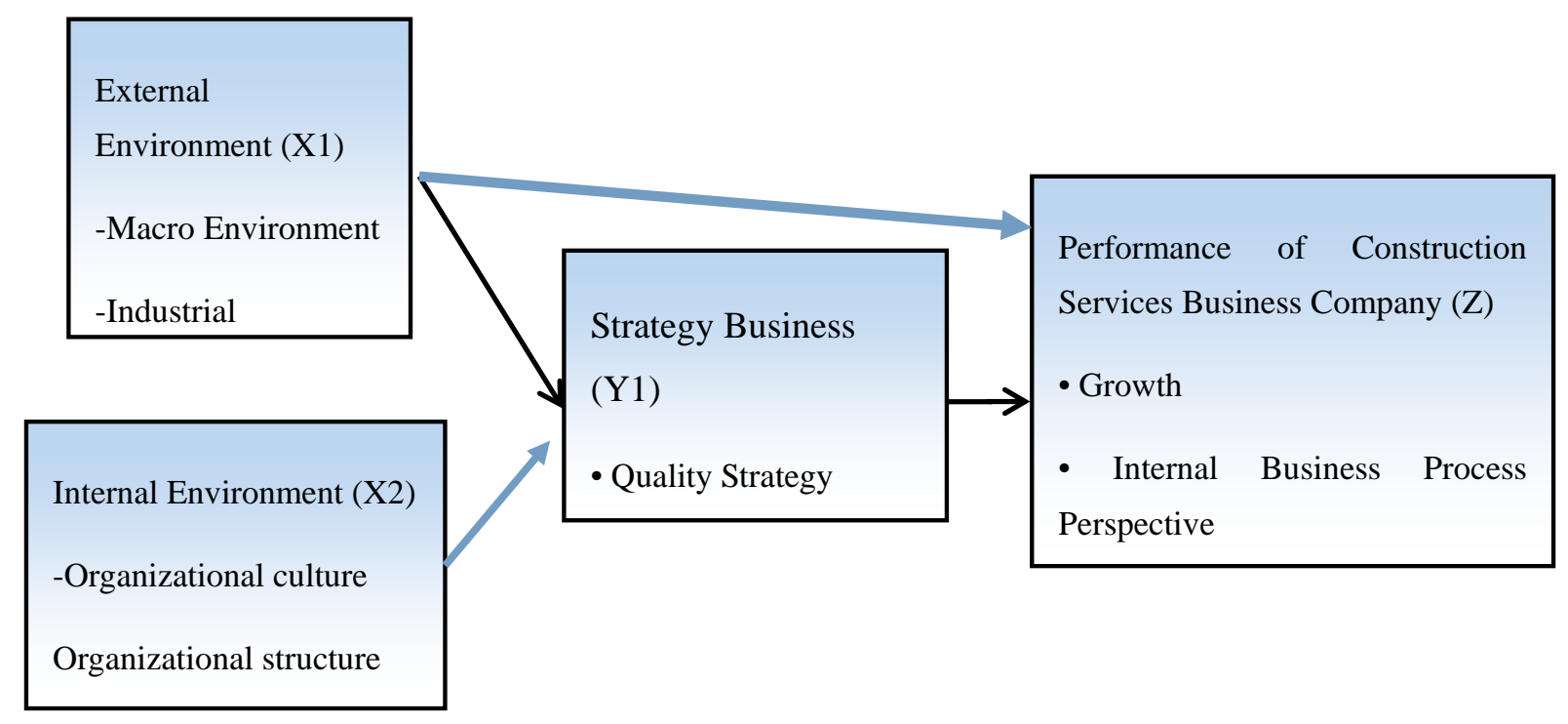

Note :

X1: External Environment

X1.1: Macro Environment

X1.2: Industrial Environment

X2: Internal Environment

X2.1: Organizational Culture

X2.2: Organizational Structure 
X2.3: Organizational Resources

Y1: Business Strategy

Y1.1: Quality Strategies

\section{Y1.2: Partnership Strategy}

Z: Performance of Construction Service Company (integration of balance scorecard and malcolm baldrige performance)

Z1: Growth perspective

Z2: The internal perspective of business processes

Z3: Consumer perspective

Z4: Financial perspective

A good model is a model with no correlation between independent variables and multicollinearity and heteroscedasticity tests. Test results can be seen from the relationship in the coefficient matrix free variable, if there are correlation coefficient more than $80 \%$ there is indication multicollinearity. Regression models with heteroscedasticity have a serious impact on OLS estimators, therefore BLUE testing needs to be done. If there is heteroscedasticity means all variants on the variable has a constant variant. Testing is done by following the following test criteria.

H0: $\mathrm{t}$ arithmetic $>\mathrm{t}$ table, $\mathrm{H} 0$ rejected or accept (Ha) means free variable partially does not affect the dependent variable

Ha: $t$ arithmetic $>$ t table, Ha accepted or rejected (Ho) means free variables partially affect the dependent variable

H0: F arithmetic > F table, H0 rejected or accept (Ha) means free variable simultaneously does not affect the dependent variable

H0: F arithmetic > F table, H0 accepted or rejected (Ho) means free variables simultaneously affect the dependent variable

\section{Findings and Discussions}

Model testing is done to determine the level of validity and reliability. Test results can be put forward as follows: The result of loading factor test resulted above value is suggested that is equal to 0,5 , so that indicator which used in research show valid. Further, the loading factor test results for external, internal, strategy and performance dimensions have a higher loading factor than with constructs and have good discriminant validity. Meanwhile the reliability test result is done by looking at the composite reliability and Cronbach's alpha. Value, indicating the external indicator is reliable at the recommended value level is above 0.6 and p value less than $5 \%$. Structural model testing is performed to test the relationship between latent constructs. 
There are several stages and tests for the structural model as follows. Square on endogenous constructs. $\mathrm{R}$ Square value is the coefficient of determination in endogenous constructs. $\mathrm{R}$ square values are:

Table 2. R Square

\begin{tabular}{|l|l|l|l|}
\hline & Original Sample (O) & $\begin{array}{l}\text { T Statistics } \\
(\mid \mathbf{O} / \text { STDEV|) }\end{array}$ & P Values \\
\hline Strategy & 0,805 & 69,639 & 0,000 \\
\hline Performance & 0,855 & 91,655 & 0,000 \\
\hline
\end{tabular}

R square value of above 0.67 (strong) with p value less than 5\% indicates that strategy and performance can be explained by strong business environment. Estimate for Path Coefficients, is the coefficient value of the path or the relationship of latent construct. Performed by Bootrapping procedure. Effect Size (f square), used to know the goodness of the model.

Table 3. Effect Size (f square)

\begin{tabular}{|l|l|l|l|}
\hline & $\begin{array}{l}\text { Original } \\
\text { Sample (O) }\end{array}$ & $\begin{array}{l}\text { T Statistics } \\
(|\mathbf{O} / \mathbf{S T D V}|)\end{array}$ & P Values \\
\hline External -> performance & 0,000 & 0,047 & 0,962 \\
\hline External -> strategy & 0,063 & 1,871 & 0,062 \\
\hline Internal -> performance & 0,298 & 3,956 & 0,000 \\
\hline Internal -> strategy & 2,470 & 9,846 & 0,000 \\
\hline Strategy -> performance & 0,335 & 5,244 & 0,000 \\
\hline
\end{tabular}

The above table shows that the value of $\mathrm{p}$ value for the relationship of all variables is less than $5 \%$ or $10 \%$, except for external relations to $5 \%$ or $10 \%$ performance, this indicates that the effect of the external environment on the performance of the construction service is not good, or the external environment affect the performance of construction services. Prediction relevance (Q square) otherwise known as Stone-Geisser's. This test is performed to determine predicted capability with blindfolding procedure. If the value obtained 0.02 (small), 0.15 (medium) and 0.35 (large). Can only be done for endogenous constructs with reflective indicators.

Table 4. SSO and SSE Result

\begin{tabular}{|l|l|l|l|}
\hline & SSO & SSE & $\begin{array}{l}\mathbf{Q}^{2} \\
(=\mathbf{1 - S S E} / \text { SSO })\end{array}$ \\
\hline External & 680,000 & 680,000 & \\
\hline Internal & $1.020,000$ & $1.020,000$ & \\
\hline Strategy & 680,000 & 153,335 & 0,775 \\
\hline performance & $1.360,000$ & 569,982 & 0,581 \\
\hline
\end{tabular}

The value of Q2 is greater than 0.35 . This shows the endogenous value of strategy and performance is large and has been eligible. The structural model in the PLS is evaluated by 
using R2 for the dependent variable and the coefficient value on path $(\beta)$ for the independent variable which then assessed its significance based on the T-statistic value of each path. The size of significance of hypothesis support can be used comparison of T-table and T-statistics. If the T-statistic value is higher than the T-table value, then the hypothesis is accepted. For a 95 percent confidence level (alpha 5 percent), the T-table value for the two-tailed hypothesis is $\geq$ 1.96 and for the one-tailed hypothesis is $\geq 1.64$. To assess the significance of the prediction model in the test of the structural model (inner model), it can be seen from the T-statistic value between the independent variables to the dependent variable in the path coefficient table on the Smart PLS output as follows.

Table 5. T Statistics Result

\begin{tabular}{|l|l|l|l|}
\hline & $\begin{array}{l}\text { Original Sample } \\
(\mathbf{O})\end{array}$ & $\begin{array}{l}\text { T Statistics } \\
(\mid \mathbf{O} / \text { STDEV|) }\end{array}$ & P Values \\
\hline External -> performance & $-0,006$ & 0,249 & 0,804 \\
\hline External -> strategy & 0,131 & 3,804 & 0,000 \\
\hline Internal -> strategy & 0,457 & 10,039 & 0,000 \\
\hline Internal -> strategy & 0,821 & 35,591 & 0,000 \\
\hline Strategy -> performance & 0,498 & 9,733 & 0,000 \\
\hline
\end{tabular}

The value of $p$ values is less than $5 \%$ for all exogenous to endogenous connections, except for the influence of the external environment on performance, it shows that there is no external environment influence on the performance of construction services. The negative value indicates the greater the threat of the external environment, the performance of construction services will decrease. As for assessing the significance of the prediction model in testing the structural model (inner model) the effect of mediation can be seen in the table below.

Table 6. Structural Model Result

\begin{tabular}{|l|l|l|l|l|}
\hline & External & Internal & Strategy & Performance \\
\hline External & & & & 0,065 \\
\hline Internal & & & & 0,409 \\
\hline Strategy & & & & \\
\hline performance & & & & \\
\hline
\end{tabular}

In the moderation effect test, the output of the test parameter is shown in the total effect table, not in the table path coefficients, since the moderation effect is not only a direct effect of the independent variable to the dependent variable but also the interaction relationship between the independent variable and the moderation variable against the dependent variable (indirect effect). Therefore, total effects are used to see the effect of total predictions (direct and indirect effect). Based on the total effect table result of interstration bootstrapping obtained T-statistic value of moderation variable $<1,96$. The testing of moderation effects can be seen in the following table. 
Table 7. Moderation Effect Result

\begin{tabular}{|l|l|l|l|l|}
\hline & External & Internal & Strategy & Performance \\
\hline External & & & 0,131 & 0,059 \\
\hline Internal & & & 0,821 & 0,865 \\
\hline Strategy & & & & 0,498 \\
\hline performance & & & & \\
\hline
\end{tabular}

\subsection{Influence of External environment}

The results of research on the influence of the external environment on the business strategy and the performance of the construction service shows the organization environment of the construction service company, both aspects of technological development and competition climate. Aspects of technological development include construction service providers are also still weak in adopting the development of existing technology, especially on smaller contractors who number more. The competitive climate aspect includes national construction service providers in competition with foreign construction service providers entering the national construction market. For clarity can be followed on the chart as follows.

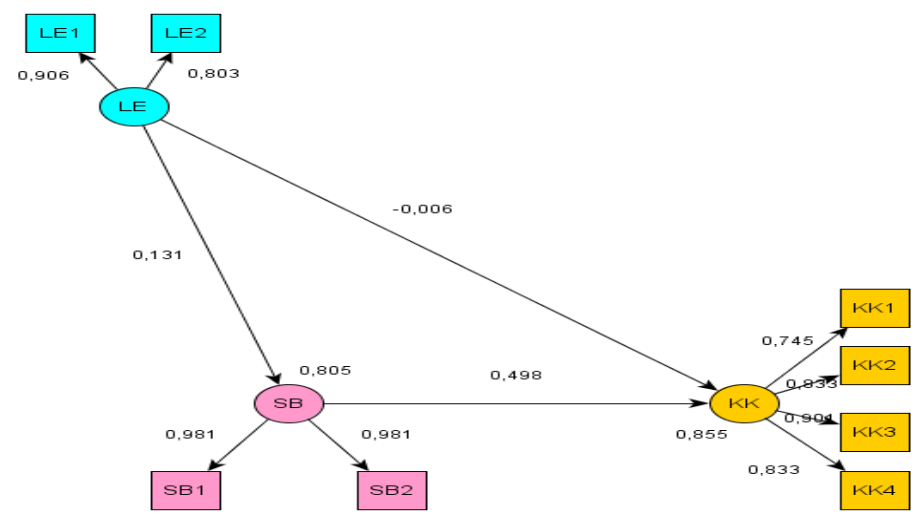




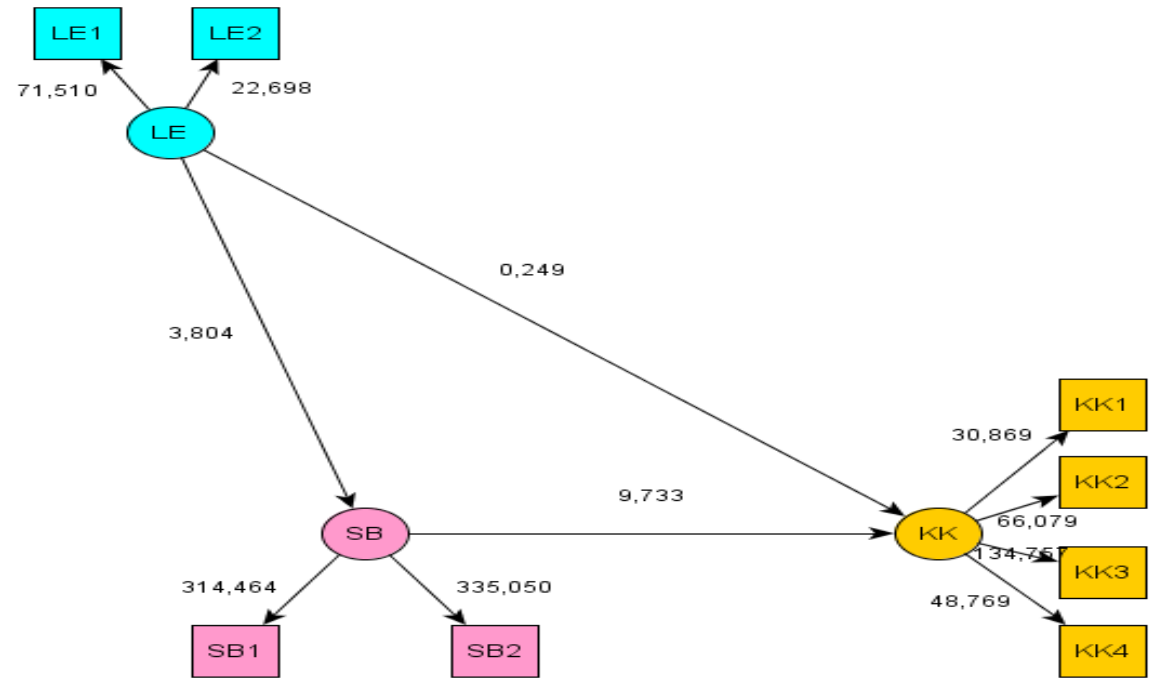

Table 8. Hypothesis Result

\begin{tabular}{|c|c|c|c|c|c|c|}
\hline & $\begin{array}{l}\text { Original } \\
\text { Sample } \\
\text { (O) }\end{array}$ & $\begin{array}{l}\text { T Statistics } \\
(|\mathrm{O} / \mathrm{STDEV}|)\end{array}$ & P Values & $\mathbf{R}^{2}$ & $\begin{array}{l}\text { Total } \\
\text { Effect }\end{array}$ & Decision \\
\hline $\begin{array}{l}\text { External } \\
\text { performance }\end{array}$ & 0,131 & 3,804 & 0,000 & 0,805 & & $\begin{array}{l}\text { Accepted } \\
\text { H1 }\end{array}$ \\
\hline $\begin{array}{l}\text { External } \\
\text { performance }\end{array}$ & $-0,006$ & 0,249 & 0,804 & 0,855 & & $\begin{array}{l}\text { Rejected } \\
\mathrm{H} 1\end{array}$ \\
\hline $\begin{array}{l}\text { Strategy } \\
\text { performance }\end{array}$ & 0,498 & 9,733 & 0,000 & 0,855 & & $\begin{array}{l}\text { accepted } \\
\text { H1 }\end{array}$ \\
\hline $\begin{array}{l}\text { External -> strategy-> } \\
\text { performance }\end{array}$ & & & & & 0,059 & \\
\hline
\end{tabular}

Result of research The influence of external environment on business strategy shows that the influence of external environment on competitive strategy is positive and significant because $p$ Values less than 0.05 this indicates that there is influence of external environment to strategy and the bigger influence external environment in construction service industry hence manager the greater the anticipation of changes in the external environment. The value of R2 is $80.5 \%$. It shows that the business strategy model can be explained by the external environment of $85.5 \%$ and shows that business strategy can be explained strongly by the external environment. The external environment determines the right competitive strategy to apply. A good environmental observation will result in a more appropriate competitive strategy plan either through a partnership strategy and a quality strategy, therefore a process environmental observation becomes one of success factor of strategy applied by company which in the end will get high performance. Collecting information on environmental aspects can facilitate the adjustment between several competitive strategies with the business environment where a 
good strategic plan contains at least a picture of the current and future business environment of the company and senior managers should first observe the environment (environmental scanning) in order to obtain adequate external information as a basis for strategic decision-making. Several business strategies are applied to anticipate the development of turbulent macro economic environment change for construction service as follows: Social, Cultural, Demographic Aspects; The increasing number of middle-class residents which led to the increase in value of construction projects especially for property. Political Aspects, Laws; There has been an affirmative action from the Ministry of Energy and Mineral Resources that can be used as a model to enable BUJK to develop and the association is entitled to report if there is a violation in the case of contract. The existing political conditions are felt conducive to the acceleration of development. There is a regulation that protects domestic producers and consumers (Investment Law and Consumer Protection Law as well as procurement arrangements and regulations on the preference for the use of domestic production products). Aspects of Technology Developments; The rapid development of technology which is balanced by the mastery of national technology is good enough so that the national technology development is quite good. This is evident from the colossal landmark buildings and robust infrastructure spread over the Indonesian territory as evidence of national technology development and development; Research in terms of construction technology conducted by experts / intellectual communities, LPJK and others are very sensitive to the existing developments. Climate Competition Aspect, With the 2015 MEA, it will open up opportunities to enter ASEAN market while maintaining for the mastery of the construction market by local construction service providers supported by skilled and expert Indonesian-Indonesian quality.

The result of the External Environment Impact on the Construction Services Business Performance shows that there is no external environment influence on the performance, because $\mathrm{p}$ value is greater than 5\%. The external environmental relationship with the performance of construction services is negative, indicating that the greater the threat of the external environment the performance of construction services will decrease. The value of R2 is $85.5 \%$, it shows that the performance of construction services can be explained by the external environment strongly equal to $85.5 \%$. The external environment is an environment that is outside the organization and needs to be analyzed to determine the opportunities and threats that will be faced by the company. This external environment develops too dynamic if not anticipated with the right strategy then the performance of construction services will actually decrease. Several causes causing the performance of construction services to decline according to survey results are: 1) unemployment placement, 2) low technology use intensity, 3) lack of coordination among construction service business actors (no cooperation in resource utilization, joint operation, marketing cooperation, development cooperation and research), 4) not maximal functioning of institutions for cooperation between construction service actors, government and universities, 5). unhealthy structure and competition, 6). the ability of managers of construction services business that is still not optimal, 7) not too demanding (demand sophistication) the users of construction services in quality and time, 8) 
the industrial structure is not ideal and 9) the transaction cost is too high. Furthermore some external environmental threats are as follows: Economic Aspect: The global economic crisis, mainly due to the low exchange rate of rupiah in addition to Indonesia is a country importing both raw and ready materials so that the dependence on rupiah exchange rate and imports is quite high; The limited funding by the state on the amount of budget needed for infrastructure development and public financing for infrastructure development is still low; The capability of the capital of construction service providers is still low / weak, plus the bank interest rate is still high and the Government has not facilitated loan capital loan for SMEs; unstable building material prices, decreasing demand, and high levels of competition; contractors also have to face payments that often report very long or not according to the agreement even sometimes not paid. Political, Legal and Governance Aspects: the construction sector has not become the mainstream of economic development, so the priority for the national construction sector is low; Inhibiting bureaucracy and a culture of high corruption. From the construction sector, the procurement process of non-governmental construction works indicates a covert engagement of contractors' agreements and also tends to attempt to influence / regulate the bidding process; Law enforcement on the orderly implementation and utilization of these regulations is not yet firm; The existence of regional autonomy indirectly can cause the program to be implemented is not sustainable; Information Communication Technology (ICT), has not been used effectively by national construction companies. Technology, application and technology development felt less rapidly so that the added value is less high compared to the others.

The result of research on the influence of business strategy on the performance of construction service shows that the influence of business strategy on performance is positive and significant with R2 equal to 85,5\%. The positive coefficient shows that the higher the business strategy which is applied then the performance of construction services will increase. The business strategy affecting the performance of construction services is shown at p value less than $5 \%$. The value of R2 indicates that business performance can be strongly explained by the business strategy. A properly implemented business strategy by anticipating a dynamically changing business environment, the performance of construction services will increase, as shown in the following way: Human resource management function is needed to manage human resources owned company so as to produce maximum human resource output. When viewed from the organizational structure, HR functions can be said to run quite well, each - each position has a job description and job specification. However, the company's human resources management is still captured by the director. The number of employees who are still not too much and the level of complexity of HR management is still low to be the reason why the top management does not make and appoint an HR manager in this company.

Products are goods or commodities that are the object of the company's business. The product here leads to the many types of products or product variants offered by the company. Consumers in this industry is a construction project that certainly has many needs ranging from raw materials such as cement, bricks to light or heavy equipment such as locks, hammers, helmets, heavy equipment, and so forth. Surely a construction project has deadlines to be pursued, project completion must be timely and no defects. When looking for a place to 
buy the needed equipment, the project will certainly find a provider that can answer almost all of its needs, because the project does not have much time to search for some companies to answer their needs. Companies that offer an enormous product line will be the main preference for construction projects. If you look at the product line offered by company, the company has a product line with an amount almost equal to its competitors. The excess of the company is the company rarely experienced out of stock or no stock when consumers make a purchase order. When a particular product runs out, the company can immediately take the product from the suppliers who provide the product. Supported by contractual ties with the company's shipping company can immediately bring the goods to be delivered to the consumer or directly send to the consumer through the expedition without entering the company first. Service; providing good service means delivering what consumers demand and responding to customer needs. Referring to the results of observations on the flow of business transactions, the company does not hesitate to ask what is desired and what is needed by consumers. Thus the company can provide the right product specifications in accordance with the will and needs of consumers. In addition, the company also provides free seminars and training around the use of products to its customers within a certain period of time. This is what makes consumers loyal to the company in search of its needs.

Marketing; Another key factor comes from the marketing aspect. Although the company does not actively engage in marketing activities through media such as print and electronic media, marketing continues to play an important role in the growth of the company. The marketing department deals directly with both consumers and suppliers, of course, customer satisfaction is determined by the marketing department as well. The marketing department not only does its job of selling products but also conducts follow-up and fostering good relationships with consumers. In addition to determining the right marketing strategy, survey activities on market conditions and competitive conditions are common, although surveys are not conducted directly, mostly derived from the info that appears from consumers, salesmen from some suppliers and see for themselves to the field (project review and other companies). Partnerships, good integration with consumers and suppliers are important factors for the company. In addition to beneficial in other transactions for the future, a good relationship will make consumers and suppliers to be a means of promotion of word of mouth about the company to others. The results show that the external environment supported by business strategy will increase the performance of construction services, it is proven because the external environment to the business strategy and the performance of construction services is greater than the influence of the external environment on the performance of construction services and in fact the external environment has no effect on the performance construction service

\subsection{The Influence of the Internal Environment}

The result of research of internal environment influence to business strategy and performance of construction service can be seen there is following chart. 

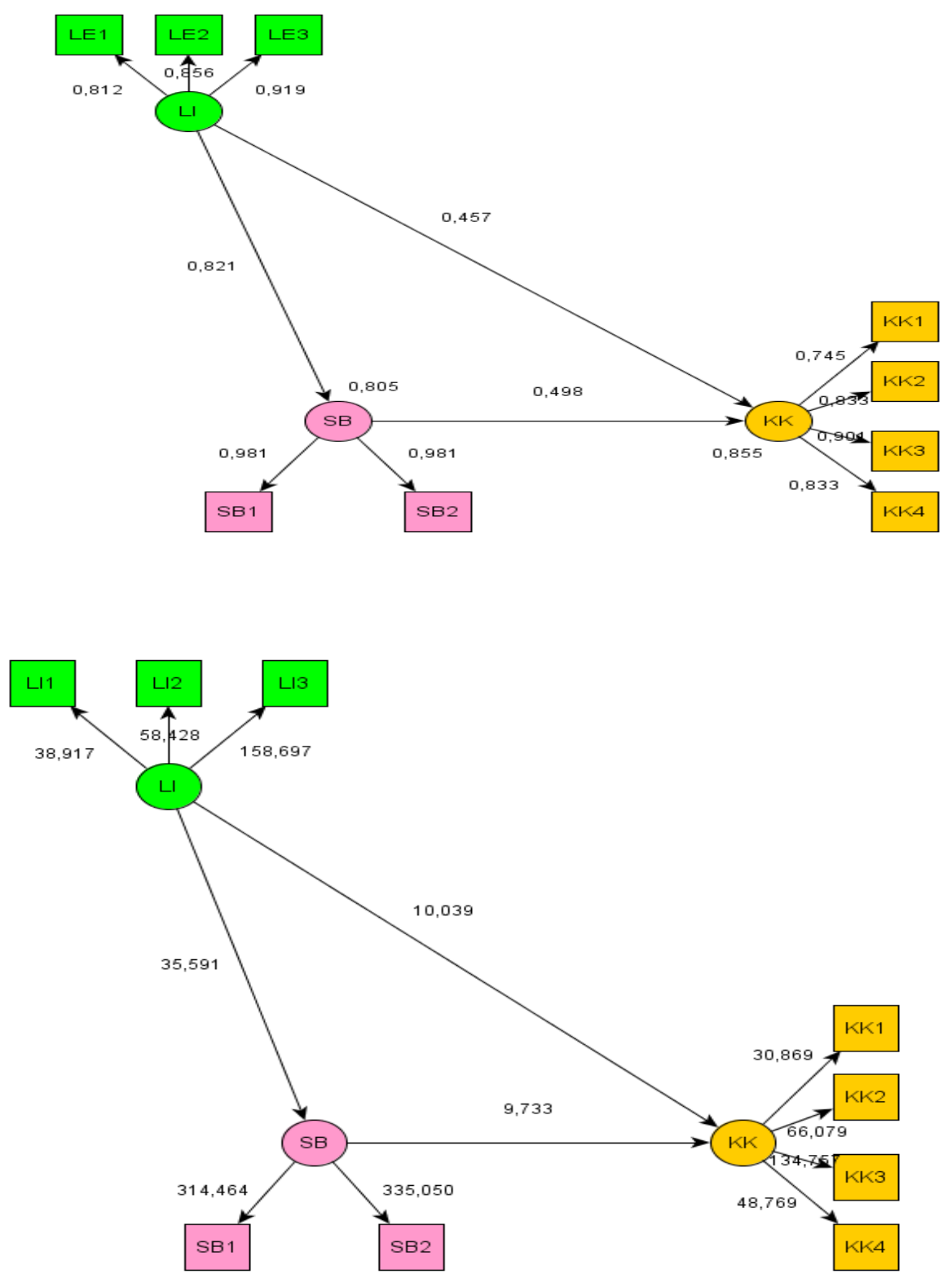

Table 9. Internal Environment Result

\begin{tabular}{|ll|l|l|l|l|l|l|}
\hline & & $\begin{array}{l}\text { Original } \\
\text { Sample } \\
\mathbf{( O )}\end{array}$ & $\begin{array}{l}\mathbf{T} \text { Statistics } \\
(|\mathbf{O} / \mathbf{S T D E V}|)\end{array}$ & $\begin{array}{l}\mathbf{P} \\
\text { Values }\end{array}$ & $\begin{array}{l}\text { Total } \\
\text { Effect }\end{array}$ & $\mathbf{R}^{2}$ & Decision \\
\hline $\begin{array}{l}\text { Internal } \\
\text { strategy }\end{array}$ & $->$ & 0,821 & 35,591 & 0,000 & & 0,805 & $\begin{array}{l}\text { accepted } \\
\text { H1 }\end{array}$ \\
\hline $\begin{array}{l}\text { Internal } \\
\text { performance }\end{array}$ & $->$ & 0,457 & 10,039 & 0,000 & & 0,855 & $\begin{array}{l}\text { accepted } \\
\text { H1 }\end{array}$ \\
\hline $\begin{array}{l}\text { strategy } \\
\text { performance }\end{array}$ & $->$ & 0,498 & 9,733 & 0,000 & & 0,855 & $\begin{array}{l}\text { accepted } \\
\text { H1 }\end{array}$ \\
\hline
\end{tabular}




\begin{tabular}{|l|l|l|l|l|l|l|}
\hline Internal -> & & & & 0,865 & & \\
strategy $>$ \\
performance
\end{tabular}

The results of Internal Environmental Impact on Business Strategy show that the internal environment influence on strategy is significant and positive. This significant effect is seen in $\mathrm{p}$ values less than 5\%; Furthermore, positive values indicate that the greater the threat of the internal environment then the strategy applied will also increase. Value R2 of 0.805, this indicates that the business strategy model can be explained by the internal environment is strong by $80.5 \%$. The internal environment is the environment within the organization that needs to be analyzed to know the strengths and weaknesses that exist within the company. The internal environment should be anticipated with the right strategy, in the following way: Organizational culture; planting value will form the character of employees, culture also will be created in accordance with the value applied. Companies always give freedom of opinion and try to involve all employees in decision making. This can make the decision-making system, both strategic decisions and for day-to-day operational activities of the company longer because they have to listen to the opinions of each employee first; Freely organized leadership style and work culture within the company sometimes make decision making a little slower because it takes an opinion from several parties. But for some decisions that greatly affect the company's performance remains a central decision (only upper management only); Free culture but regular and timely support the company get good imaging from consumers and suppliers in the environment industry, both in terms of speed of service and answer the demand for goods. The division of the organizational structure also encourages the working environment to be made in such a way as to support the performance of company employees. Corporate culture supports employees to freely argue and work freely.

The organizational structure is also not so complicated that employees can easily understand the task and must make a report of responsibility to whom. However, the training provided by the company to employees can be said to be still lacking because not all divisions get training in accordance with their respective fields; The division of the organizational structure also encourages the working environment to be made in such a way as to support the performance of company employees. The organizational structure is also not too complicated so that employees can easily understand the task and must create a report of responsibility. Observing the organizational structure, the company does not have standard SOP (Standard operating Procedures). Indeed there are some corporate functions that are caught like HRD and purchasing function. But the organizational structure is quite clearly divided into several divisions, so that the delivery of information, duties, obligations and responsibilities of each position is clear. Clearly in the sense that every employee understands the duties, obligations, responsibilities of each. Source; a) Financial resources The money resources in this company mostly come from bank loans. Of course, financial management in this company is quite strict because it is not only overseen by human resources, but is supported by a financial oversight program that will provide a warning if there is a debt or accounts receivable b) 
Human resources The company prioritizes the character and willingness to learn in accepting employees new versus skills as well as educational background. Companies are more aimed at an atmosphere of togetherness and kinship in work than to build an atmosphere of interconnectedness with each other. Thus the company employees not only focus on pursuing individual targets but paying attention to co-workers and working together as a team. c) Physical resources, Physical resources include information technology and support facilities used by the company. d) Intangible resources. Currently the company offers some products that are already known by consumers and some are still not known by consumers. Companies dare to market products that are not too well known by consumers because the company believes the quality of the brand and the opportunity consumers want to buy the product is high enough. When the brand is well-known, the company hopes to get the agency's cooperation and contract on the brand so that the company's competition position will be slightly stronger than its competitors.

\subsection{The result of research of Internal Environment Influence on Construction}

Service Performance shows that the influence of internal environment on the performance of construction services is significant and positive. This significant effect is seen in p values less than 5\%; Furthermore, positive values indicate that the greater the threat of the internal environment then the strategy applied will also increase. Value R2 of 0.855 , this shows that the business strategy model can be explained by the internal environment strongly equal to $85.5 \%$. The internal environment is the environment within the organization that needs to be analyzed to know the strengths and weaknesses that exist within the company. Internal environment in this case is the culture, structure and resources must be anticipated so that company performance increases. The result of research of internal environment influence to business strategy and construction performance is bigger than internal environment influence to construction service performance. This shows the internal environment within the organization that is the culture, structure and source of the organization should be anticipated with the right strategy so that the performance of construction services will increase.

Impact on the performance of construction service firms as measured by Malcolm Baldrige's integration model and Balance Scorecard in Jakarta's Special Capital Region. Population is contractor of big and medium company of construction service from model of Krejcie and Morgan (Uma Sekaran, 2012). The sampling

\section{Conclusion}

It can be concluded that (1) the external environment has a positive effect on business strategy, it shows that the higher the threat of external environment that is macro environment and competition analysis it is necessary to apply the right business strategy to anticipate through the quality of strategy and partnership; (2) the external environment has no effect and negatively on the performance of construction services, it shows that the higher the threat of the external environment of the organization, the performance of construction services, the performance of construction services will increase because construction service companies can not implement 
the right strategy to anticipate; (3) business strategy positively affects the performance of construction services, it shows the more appropriate the implementation of business strategy through the quality of strategy and partnership strategy, the performance of construction services will increase; (4) the external environment affects the performance of construction services through business strategy, it shows that the dynamic influence of the external environment explores the macro power and competition analysis it is necessary to implement the right strategy through business quality and partnership strategy, the performance of construction services will be increasing.

Further, (1) the internal environment has a positive effect on business strategy, it shows that the higher the internal environment threat that is the culture, structure and the source of the organization, it is necessary to apply the right business strategy to anticipate through the quality of strategy and partnership; (2) the internal environment has a positive effect on the performance of construction services, it shows that the higher threat of internal environment of the organization, the performance of construction services will increase because construction service companies cannot implement the right strategy to anticipate; (3) business strategy positively affects the performance of construction services, it shows the more appropriate the implementation of business strategy through the quality of strategy and partnership strategy, the performance of construction services will increase; (4) the internal environment affects the performance of construction services through business strategy, it shows that the dynamic influence of the internal environment through the culture, structure and sources of the organization it is necessary for the implementation of appropriate strategies through business quality and partnership strategy so that the performance of construction services will increase

\section{References}

Abu Bakar, A. H., Tabassi, A. A., Razak, A. A., \& Yusof, M. N. (2012). Key Factors Contributing to Growth of Construction Companies: A Malaysian Experience. World Applied Sciences Journal, 19(9), 1295-1304.

Mulla, A., \& Desai. G. (2015). Supply Chain Management: Effective Tool in Construction Industry International. Journal of Novel Research in Engineering and Science, 2(1), 35-40.

Armstrong, Kotler. (2015). Marketing an Introducing. England: Pearson Education, Inc.

Robert, A., \& K'Obonyo, P. (2012). The Relationship between Strategic Planning and Firm Performance. International Journal of Humanities and Social, 2(22), 201-213.

Cao, M., \& Zang, Q. (2011). Supply Chain Collaboration: Impact on Collaborative Advantage and Firm Performance. Journal Operation Management, 29(3), 163-180.

Cravens, W. D. (2000). Strategic Marketing (6th ed.). Boston, Mass.; London: McGraw-Hill

Clemons, E. K. (2015). Using Scenario Analysis to Manage Strategic Risk Reengineering. Sloan Management Review, 36(4).

Dauda, A., \& Ismail, M.Y. (2013). Influence of Environmental Factor Technology on Strategic 
Choice of Selected Manufacturing Companies in Nigeria Food and Beverage Industry. International Journal of Business, Humanitarian and Technology, 3(8).

Wibisono, E., Mardiono, L., \& Lukas, J.F. (2009). Integrating Balanced Scorecard and Malcolm Baldrige National Quality Award: Case Study at Distribution Company. 2nd Asia-Pacific Conference on Manufacturing Systems, 4-5 November, Yogyakarta, Indonesia

Pulaj (Brakaj), E., Kume, V., \& Cipi, A. (2015). Impact of Generic Competitive Strategy on Organizational Performance, Evidence From the Context of Albania. European Scientific Journal, 11(28).

Flynn, B., \& Huo, B. (2010). The Impact of Suplly Chain Integration on Performance: A Contingency and Configuration Approach. Journal of Applied Business and Economics, 17.

Vincent. G. (2011). Integrated Performance Management System Balanced Scorecard with Malcolm Baldrige and Lean Six Sigma Supply Chain Management. Jakarta: PT Gramedia Pustaka Utama.

Hammer, M., \& Champy, J. (2003). Reengineering the Corporation: A Manifesto for Business Revolution, Harper Business The Mediating Role of Manufacturing Flexibility under Trust Theory

Porter. (2008). The Five Competitive Forces That Shape Strategy. Harvard Business Review.

Now, Uma. (2012). Research Methods for Business: A Skill Building Approach (4th Ed).

Ionut, S. A. (2015). Managing Transformation: Business Process Reengineering or Total Quality Management. International Journal of Academic Research in Business and Social Sciences, 5(5).

Megat Tajuddin, M. Z., Ibrahim, H., \& Ismail, N. (2015). Relationship Between Innovation and Organizational Performance in Construction Industry in Malaysia. Universal Journal of Industrial and Business Management, 3(4), 89. https://doi.org/10.13189/ujibm.2015.030402.

Ting Chi. (2015). Business Contingency, Strategy Formation, and Firm Performance: An Empirical Study of Chinese Apparel SMEs. Adm. Sci, 5, 27-45. https://doi.org/10.3390/ admsci5020027

Uchegbulam, Princess, Akinyele, Samuel, lbidunni, Ayodotun. (2015). Competitive Strategy and Performance of Selected SMEs in Nigeria. International Conference on African Development Issues (CIJ-ICA DI) 2015: Social and Economic Models for Development Track

Xu, D., Zhao, L., Li, G., \& Sun, L. (2010). The Effect of Environmental Uncertainty on Supply Chain Integration in Chinese Manufacturing Industry. 7th International Conference on Service Systems and Service Management. https://doi.org/10.1109/ICSSSM.2010.5530165 


\section{Macrothink}

Business Management and Strategy ISSN 2157-6068 2018, Vol. 9, No. 1

Yu, W., Jacobs, M.A., Salisbury, W. D., \& Enss, H. (2013). The Effects of Supply Chain Integration on Customer Satisfaction and Financial Performance: An Organizational Learning Perspective. International Journal Production Economics, 146, 346-358. http://dx.doi.org/10.1016/j.ijpe.2013.07.023

Tan, Y., Shen, L., \& Yao, H. (2011). Sustainable construction practice and contractors' competitiveness: A preliminary study. Habitat International, 35(2), 225-230. https://doi.org/10.1016/j.habitatint.2010.09.008

\section{Copyright}

Copyright for this article is retained by the author(s), with first publication rights granted to the journal.

This is an open-access article distributed under the terms and conditions of the Creative Commons Attribution license (http://creativecommons.org/licenses/by/4.0/). 